\title{
Концепція розробки інтелектуальної системи діагностики захворювань
}

Розглянуто концепџії розробки інтелектуальної системи діагностики захворювань. Проведено огляд сучасних медичних інтелектуальних інформаційних систем. Подано структуру інтелектуальної системи діагностики захворювань. Детально описано етапи розробки концептуальної моделі системи.

Ключові слова: інтелектуальна система, база даних, база знань, механізм нечіткого логічного виведення, концептуальна модель, вербальна модель, нечітка множина, лінгвістична змінна, нечітке правило, функція належності.

\section{Вступ. Загальна постановка проблеми \\ Розвиток інформаційних технологій сприяв створенню великої кількості медичних інформаційних систем від автоматизованих до інтелектуальних систем підтримки прийняття рішень. Складність взаємодії при прийнятті рішень, відсутність стандартизації в термінології і шкалах вимірів, дані і знання, що погано формалізуються, ускладнюють процес використання інтелектуальних систем у медичній царині. Це призвело до того, що такі системи $є$ найменш дослідженою галуззю штучного інтелекту. \\ Інтелектуальні медичні системи спираються у} своєму створенні на такі критерії $[1,2]$ :

- внутрішня несуперечність і достовірність даних, отриманих про пацієнта;

- стійкість до великого числа нозологічних форм, що диференціюються, у тому числі гетерогенних за своєю природою i/або клінічними проявами;

- інтерпретація даних на основі медичних знань, що характеризуються відсутністю специфічних проявів хвороб, що ідентифікуються;

- облік асоціюючих симптомів у неявному вигляді, що враховуються лікарем;

- ухвалення рішення в умовах браку інформації про прояви хвороби у конкретного хворого;

- пояснення i обгрунтування отриманого системою рішення;

- переоцінка рішень, висловлених на попередній консультації, у випадку повторного обстеження хворого.

Перевага використання цих систем полягає в тому, що вони враховують всі особливості діагностики захворювання, дають змогу обрати найкращу альтернативу 3 усіх можливих, забезпечують доволі точне визначення діагнозу пацієнта.

(C) М. О. Спік, 2019

\section{Аналіз останніх досліджень і публікацій}

У наш час використання штучного інтелекту у медичній галузі вже не $\epsilon$ неймовірним. Більшість медичних інформаційних систем (MIC) допомагають спростити і оптимізувати процес праці лікаря, але вони не передбачають стати заміною лікарю. Головною функцією МІС є підтримка прийняття рішень лікаря у реальному часі. Поштовхом для розробки таких систем стала значна кількість лікарських помилок, які у більшості випадків призвели до смерті пацієнта. Наслідком стала розробка медичних систем, які допомагають лікарям зменшити кількість помилок при постановці діагнозу, призначенні курсів лікування і обстежень [3, 4].

Інтелектуальні системи, в тому числі і експертні системи, призначені для успішного вирішення складних задач у галузі медичної діагностики захворювань. Ефективність і достовірність результатів таких систем залежать, у першу чергу, від знань, якими вони володіють. Тобто від вмісту бази знань системи.

Останнім часом розроблено і впроваджено велику кількість систем медичної діагностики, які використовують технології штучного інтелекту (Ш).

Систему для діагностики захворювань у дітей розроблено дослідниками Науково-технічного університету в Гонконзі (The Hong Kong University of Science and Technology) [10]. Після завершення дослідження виявилося, що ШІ був значно більш точним у визначенні правильного діагнозу, ніж лікарі 3 малим досвідом, але майже таким само ефективним, як і фахівці з великим досвідом роботи.

Нещодавно розроблено систему діагностування раку - MyРath, яка може адаптуватися до різних етапів хвороби. Інформація, що міститься у системі, змінюється залежно від прогресу кожного пацієнта, крім того, вона видає хворому рекомендації щодо підготовки до операції [10].

Вчені Університету Мельбурна і Королівського коледжу Лондона розробили математичну програму 
діагностики TEXLab. Система оцінює результати комп'ютерної томографії пацієнток 3 оваріальним раком і прогнозує розвиток захворювання, визначаючи динаміку (позитивну або негативну).

Компанія Microsoft також долучилась до використання ШІ у медичній галузі. Healthcare NExT нова ініціатива компанії у галузі охорони здоров'я. Вона поєднує напрацювання медиків і дослідження Microsoft у галузі штучного інтелекту i хмарних технологій для спрощення введення даних про стан пацієнта, перебіг хвороби, допомоги у видобуванні черговості надання допомоги, у пошуку методів амбулаторного лікування. Таким чином, планується створити масштабну хмарну мережу, яка допоможе більш ефективно надавати допомогу пацієнтам. Партнером проекту стане медичний центр Пітсбурзького університету, спільно з яким Microsoft використовуватиме технологію розпізнавання мови для заміни ручного введення.

Описані вище результати показують, що інтелектуальні технології зовсім скоро стануть одним iз глобальних інструментів охорони здоров'я у діагностиці і, можливо, у лікуванні захворювань.

\section{Виділення невирішених раніше частин загальної проблеми}

Спрямованість медичних систем діагностики визначається поставленими завданнями i такими рівнями застосування:

- попередня діагностика на долабораторном етапі обстеження;

- діагностика 3 вибором оптимального методу дослідження для подальшої остаточної нозологічної ідентифікації патології;

- нозологічна діагностика 3 постановкою (обгрунтуванням) конкретного діагнозу на основі наявної інформації (клінічної і параклінічної);

- орієнтовна діагностика 3 оцінкою важкості стану як основа для прийняття рішення (керування рівнем допомоги) при загрозливих станах.

Обробка медичної інформації пов'язана 3 експертною оцінкою даних, аналізом даних i патологічних станів. Для розв'язання таких завдань використовуються різні методи: алгоритм пошуку асоціативних правил, байєсівський підхід, методи штучних нейронних мереж, алгоритми нечіткого логічного виведення та інші.

Інтелектуальна система діагностики захворювань (ICД3) призначена [1]:

- моделювати мислення лікаря-терапевта стосовно розв'язання конкретної задачі;

- формулювати певні висновки, грунтуючись на знаннях, які система має у своєму розпорядженні;

- володіти здатністю пояснювати отриманий результат (діагноз) і виконувати функції:
- асистента у зв’язку 3 необхідністю аналізу лікарем-терапевтом різних варіантів прийняття рішень;

- партнера-експерта 3 питань, що належать до джерел знань із суміжних галузей діяльності;

- консультанта недосвідчених або непрофесійних користувачів, які не мають відношення до медичної галузі.

\section{Цілі (завдання) статті}

У статті пропонується концепція розробки концептуальної моделі інтелектуальної системи діагностики захворювань, яка дає змогу виділити окремі етапи проектування системи.

\section{Основні результати дослідження}

Інтелектуальна система діагностики захворювань (ІСД3) складається 3 таких модулів [1]: інтерфейсу користувача, бази даних, бази знань, механізму виведення і має структуру, подану на рис. 1. Механізм нечіткого логічного виведення містить чотири етапи: фазифікація (введення нечіткості), нечітке виведення, композиція і дефазифікація (приведення до чіткості).

База знань (Б3) інтелектуальної системи містить: базу лінгвістичних змінних і базу нечітких правил. База даних (БД) системи містить факти (фактичні дані), за допомогою яких представляються вхідні дані, а також стан задачі, що розв'язується. Знання у вигляді фактів становлять опис об'єктів предметної галузі і відношень між ними. БД і БЗ системи створюються за допомогою таких спеціалістів: медиків-експертів (лікарів-терапевтів), інженера-когнітолога (спеціаліста-розробника інтелектуальної системи), програмістів, що здійснюють програмну реалізацію системи.

Інтелектуальна система діагностики захворювань (ICД3) - це інтелектуальна система, що містить знання спеціалістів у царині первинної діагностики захворювань, які в межах цієї сфери і своєї компетентності можуть приймати експертні рішення. Концептуальна модель ICД3 має бути адаптована до специфіки галузі, що розглядається, i перебудовуватися внутрішніми ресурсами, використовуючи механізм гнучкості. На початковому етапі розробки концептуальної моделі необхідно провести систематизацію початкових даних, що надходять до системи.

Розробка системи починається зі змістовної постановки завдання i попереднього дослідження предметної галузі. На даному етапі визначається мета завдання, його призначення і доцільність розв'язання. Визначаються обмеження, припущення і критерії оптимізації. Описується об'єкт керування. Визначаються вимоги до організації, збору і передачі вхідної інформації, порядку її контролю і корегування. 


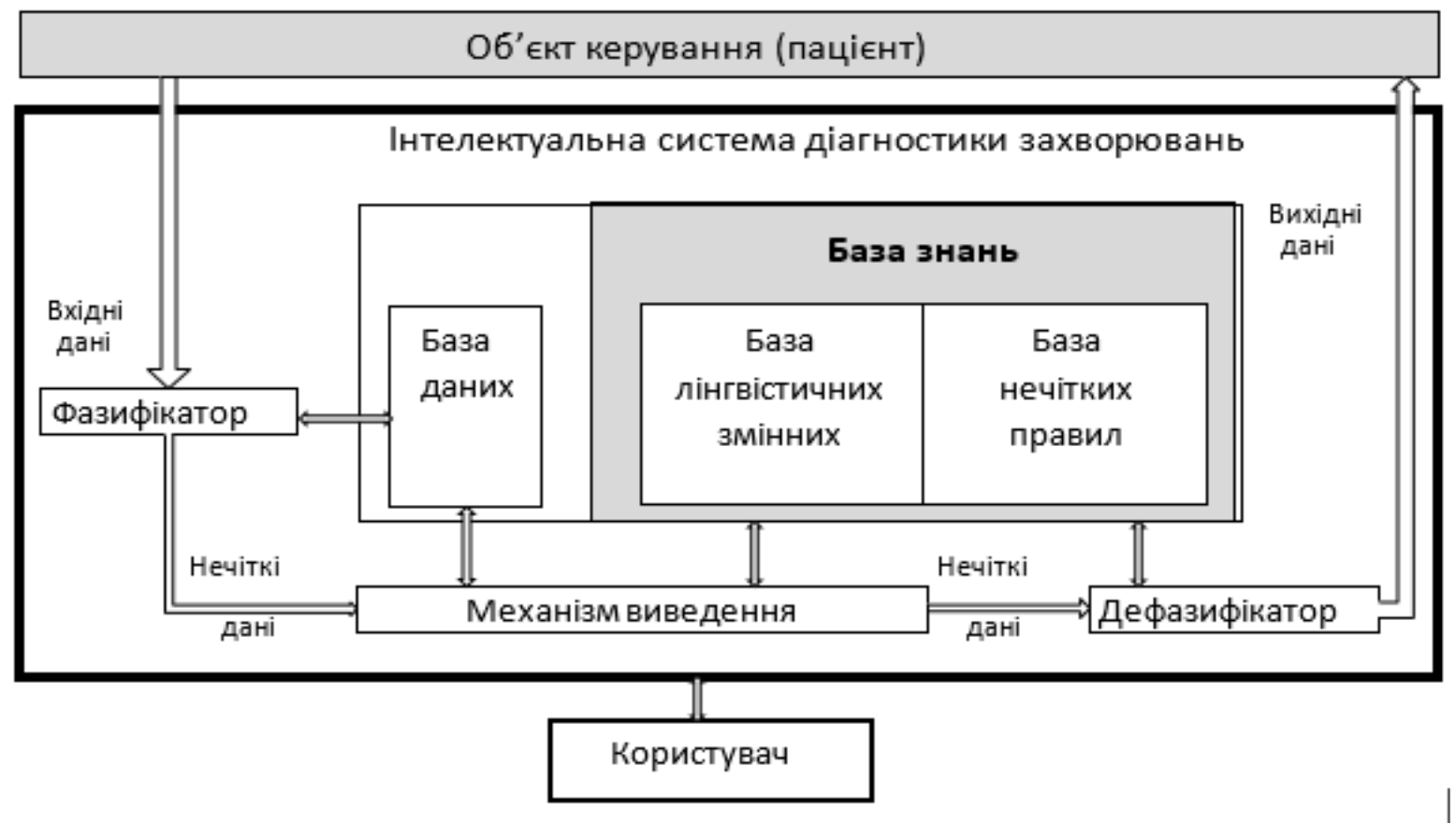

Рис. 1. Структура інтелектуальної системи діагностики захворювань

Метою завдання $є$ розробка інтелектуальної системи діагностики захворювань, яка грунтується на алгоритмі нечіткого логічного виведення. ІСДЗ має моделювати процес мислення лікаря-терапевта стосовно розв'язання конкретної задачі; формувати певні висновки, грунтуючись на знаннях, які система має у своєму розпорядженні; володіти здатністю пояснити отриманий результат (діагноз). Об'єктом керування системи є пацієнт. Вхідні дані - інформація про пацієнта (ПІБ і т. д.) і скарги пацієнта, результати загального огляду (наприклад загальний стан пацієнта, свідомість, температура тіла і т.д.). Вихідні дані - початковий діагноз, який може бути уточнений після проведення лабораторних i інструментальних досліджень.

Етап «Математичний опис системи» орієнтований на наповнення БД алгоритмами, які складають основу діяльності медиків-експертів і інженерів-когнітологів при виявленні знань, у сукупності 3 базою лінгвістичних змінних, і $€$ основою побудови бази знань системи ICДЗ. Використовується процедура структурованості або діакоптики [8], яка пропонує метод бісекції алгоритму БД на множину простіших (окремих алгоритмів) i встановлення зав'язків між ними. Крім того, це дає змогу скоротити час роботи 3 БД i обсяг оперативної пам'яті. Призначається множина алгоритмів БД, що складають основу виявлення знань.

Одним 3 найбільш важливих етапів розробки системи $є$ етап побудови вербальної моделі діагностики захворювань, який орієнтований на дії медиків-експертів (лікарів-терапевтів). Експерти керуються множиною значень лінгвістичної оцінки, що вибрана орієнтовно. При побудові вербальної моделі спочатку визначають звичайну множину елементів предметної галузі, які далі застосовуються як універсум - множина звичайних елементів однієї природи. У системі визначені такі універсуми: первинні скарги пацієнта, загальний огляд пацієнта, система органів дихання, система органів кровообігу, шлунково-кишковий тракт, печінка і жовчний міхур, селезінка, підшлункова залоза, система органів сечовиділення, ендокринна система, нервова система i органи чуття, лабораторні і інструментальні методи досліджень, постановка діагнозу. Після того, як вибраний універсум, на ньому задаються нечіткі множини, що формалізують міркування людини, лінгвістичні змінні (ЛЗ) системи і їх значення (терми). Наприклад, для лінгвістичної змінної «Температура_тіла» вказуються значення: низька, знижена, нормальна, субфебрильна, помірно підвищена лихоманка, висока лихоманка, надмірно висока лихоманка, гіперпіретична лихоманка [6]. Таким чином визначаються усі лінгвістичні змінні (ЛЗ) системи. ЛЗ для позначення температури тіла людини може бути подана у вигляді:

$<$ Температура_тіла=\{низька, знижена, нормальна, субфебрильна, помірно підвищена лихоманка, висока лихоманка, надмірно висока лихоманка, гіперпіретична лихоманка $\}, E=[0.0 ; 45.0],\{R($ низька, $e)$, 
$R$ (знижена, $e), \quad R($ нормальна, $e), \quad R($ субфебрильна, $e)$, $R($ помірно підвищена лихоманка, $e), \quad R($ висока лихоманка, $e), \quad R($ надмірно висока лихоманка, $e$ ), $R($ гіперпіретична лихоманка,е) $\}>$.

Далі призначаються носії нечітких множинних обмежень для значень лінгвістичних змінних, визначаються тип і параметри функцій належності нечітких множин.

Побудова вербальної моделі діагностики захворювань потребує участі, як мінімум, двох спеціалістів: медика-експерта та інженера-когнітолога. Вербальна модель, що передається експертом інженеру-когнітологу, може містити неповну множину правил або суперечливі правила. У ній може бути відсутньою структуризація інформації в сенсі визначення всіх можливих значень лінгвістичних змінних. Усі ці питання вирішуються інженеромкогнітологом на етапі формалізації і налаштування моделі, який володіє технологією нечіткого моделювання i визначає множину нечітких правил системи у формі $[5,6]$ :

$\Pi_{\mathrm{j}}:$ IF нлв 1 AND нлвј2 AND ... AND нлвјn THEN нлвјq $\left(v_{\mathrm{j}}\right)$,

де (vj) - ступінь достовірності правила: 3 передумови випливає висновок. Ці коефіцієнти можуть набувати значень 3 інтервалу [0, 1]. У випадку якщо ці вагові коефіцієнти відсутні, зручно прийняти, що їх значення дорівнюють 1; нлв висловлювання.

IF $R\left(X_{1}, e\right)$ AND $R\left(X_{2}, e\right)$ AND $\ldots$ AND $R\left(X_{n}, e\right)$ THEN $R($

де $R\left(X_{i}, e\right), R\left(Y_{q}, e\right)$ - нечіткі обмеження на значення вхідних і вихідних змінних.

Наведемо приклад внутрішнього подання правила для визначення типу простудного захворювання, де $R(x, e)$ - обмеження для лінгвістичної змінної:

\section{ПРАВИЛО П :}

IF $\quad R$ (Самопочуття_погіршення, $e$ AND

$R$ (Температура_тіла, $e$ ) AND $R$ (Інтоксикація, $e$ ) AND $R($ Нос_нежить_закладеність, $e) \quad$ AND $\quad R$ (Чхання, $e)$ AND $R($ Горло_біль, $e)$ AND $R($ Очі_дискомфорт, $e)$ AND $R$ (Головний_біль, $e$ ) AND

$R($ Підвищена_стомлюваність, $e$ ) AND $R($ Безсоння, $e$ )

THEN $R$ (Діагноз, $e$ )

Нечітка ідентифікація складається 3 таких етапів: визначення типу функції належності (клас $S, Y, t, L, \pi$ )
Етап «Абстрактний синтез бази знань» виконується на основі вербальної моделі. Модель, що формалізується у вигляді Б3, має задовольняти формальні вимоги, що не стосуються смислового аспекту правила. Правила Б3, що мають вигляд (1), мають бути завершеними: кількість підумов має дорівнювати кількості лінгвістичних змінних. Б3 у цілому має задовольняти умови повноти, несуперечності, зв'язності і бути мінімізованою.

Етап «Побудова бази знань» пов'язаний 3 процесом формалізації правил, що описані на етапі створення вербальної моделі. Формалізація БЗ містить такі дії:

- визначення множини вхідних i вихідних параметрів, яка повністю покриває словесний опис правил керування і числові характеристики параметрів;

- формальний опис лінгвістичних змінних;

- формальне зображення вербальної моделі у вигляді (1);

- дослідження БЗ.

Також на цьому етапі розв'язується задача нечіткої ідентифікації об'єкта моделювання - визначаються нечіткі обмеження. У нечітких системах існує дві форми подання правил у базі знань: зовнішня i внутрішня. Зовнішнє подання передбачає, що правило має бути зрозуміле фахівцеві в предметній галузі, тобто читабельне. Такий запис правила подано у вигляді (1). Внутрішне подання має бути зрозуміле механізму виведення, який використовує сенс вибраного правила. Для внутрішнього подання правила використовується запис [5, 7]:

$R\left(Y_{q}, e\right)$

і визначення параметрів для вибраного типу функції належності. Складність нечіткої ідентифікації полягає в тому, що більшість лінгвістичних змінних системи не мають чисельного виразу, визначення типу функції належності та іiі параметрів і повністю залежать від медиків-експертів, знання яких доволі часто $є$ суперечливими

Розглянемо фрагмент моделі діагностики захворювань «тривалість кашлю» $-F_{13}^{1}$. Даний

фрагмент побудований на знаннях лікарів-експертів і визначений на множині «тижні» [7]: гострий (менше 2 тижнів), затяжний (2-4 тижні), підгострий (4-8 тижнів), хронічний (більше 8 тижнів):

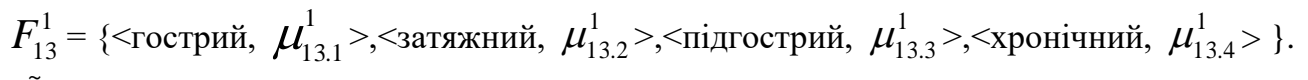

На рис. 2 зображено графіки функцій належності (клас $t$ ) фрагменту «тривалість кашлю» - $F_{13}^{1}$. 


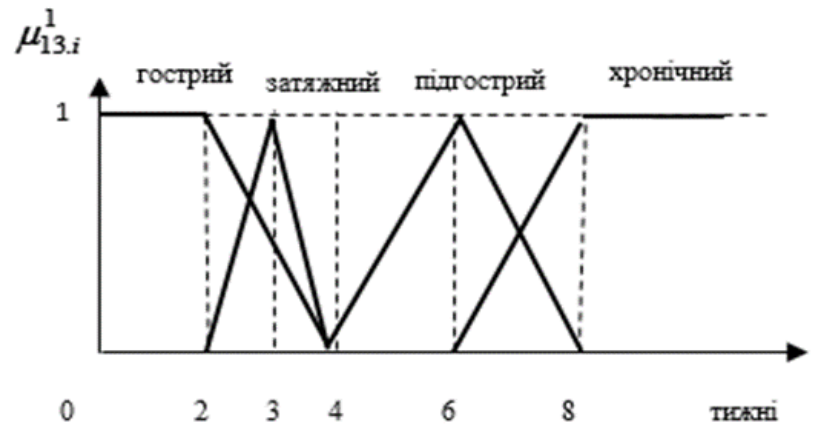

Рис. 2. Графіки функцій належності фрагменту $F_{13}^{1}$

На етапі «Налаштування бази знань», використовуючи кількість вхідних параметрів, визначення лінгвістичних змінних для кожного параметра, кількість термів і тип функції належності, будується сітка розбиття області можливих значень вихідних параметрів. Щільність сітки безпосередньо пов'язана 3 кількістю термів лінгвістичної змінної. Далі проводиться налаштування системи: побудова функцій належності і формування правил.

Етап «Мінімізація бази знань» побудовано на принципі несумісності Л. Заде, що стверджує: «І зростанням складності систем здатність формувати точні і змістовні твердження про їх поведінку падає до певної межі, за якою такі характеристики, як точність $і$ змістовність (реальність), стають взаємовиключними» [9].

Існує декілька підходів до зменшення числа правил у БЗ при збереженні ії точності:

- розбиття вхідного простору, при якому можна виграти на кількості правил;

- об'єднання близьких і схожих множин. Даний підхід оснований на посиланні, що два правила, в яких для однієї і тієї самої лінгвістичної змінної використовуються суміжні терми 3 близькими модальними значеннями, можна об'єднати в одне правило, у якого нечітка множина-обмеження отримана об'єднанням нечітких множин 3 початкових правил;

- метод локальних моделей - розбиття множини вхідних параметрів на підмножини. При цьому існує два випадки використання методу: множину вхідних параметрів можна розбити на $k$ незалежних підмножин, що не перетинаються, і вхідні параметри взаємозалежні, що заважає їх розбиттю на підмножини.

Після виконання цього етапу знову проводиться дослідження характеристик створеної Б3 на повноту, несуперечність і зв'язність.

Етап оцінки концептуальної моделі ІСДЗ орієнтований на розгляд правил визначення показників якості створення і показників якості функціонування
ICД3. Він також пов'язаний 3 перевіркою достовірності концептуальної моделі.

Перевірка достовірності містить:

- перевірку задуму моделі;

- оцінку достовірності вхідної інформації;

- розгляд постановки завдання моделювання;

- дослідження гіпотез і припущень.

Етап «Реалізація нечіткої моделі діагностики захворювань» передбачає програмну реалізацію, тестування i аналіз результатів роботи ICД3. Проводиться апробація розробленої системи діагностики захворювань за принципом зворотного зв'язку на базі знань нечітких правил.

\begin{tabular}{ccc}
\hline \multicolumn{3}{l}{ Висновки і перспективи досліджень } \\
\hline Досвід & використання & інтелектуальних
\end{tabular}
інформаційних систем у медичній царині, які грунтуються на знаннях, дає змогу стверджувати про перспективність інтелектуальних систем діагностики для розвитку медицини. Наступні дослідження будуть присвячені подальшому розробленню інтелектуальної системи діагностики захворювань, грунтуючись на методах штучного інтелекту і нечіткої логіки.

\section{Список використаних джерел}

1. Спік, М. О. Інтелектуальна система діагностики захворювань [Текст] / М. О. Спік // Proceedings of the X International Scientific and Practical Conference International Trends in Science and Technology Vol.1. - Warsaw, Poland: RS Global Sp. z O.O., 2019. - P. 3-6. ISBN 978-83-952507-6-7

2. Shuping Sun, An innovative intelligent system based on automatic diagnostic feature extraction for diagnosing heart diseases [Text] / Sun Shuping. Knowledge-Based Systems, Volume 75. Elsevier B.V.: 2015. - P. 224-238. ISSN 0950-7051, https://doi.org/10.1016/j.knosys.2014.12.001.

3. Мельникова, Н. I. Автоматизована обробка персоналізованої медичної інформації для систем підтримки прийняття рішень [Текст]: автореф. дис. ... канд. техн. наук : 05.13.06 - інформаційні технології / Наталія Іванівна Мельникова ; Національний університет «Львівська політехніка». - Львів, 2014. - 22 с.

4. Литвин, В. Інтелектуальна система підтримки прийняття рішень діагностування ревматологічних захворювань на основі адаптивних онтологій [Електронний ресурс] / В. Литвин // Lviv Polytechnic National University Institutional Repository. - 2011. - № 694. - С. 26-34. - Режим доступу : edu.ua:8080/handle/ntb/10627.

http://ena.lp.

5. Каргін, А. О. Введення в інтелектуальні машини. Кн. 1. Інтелектуальні регулятори [Текст] / А. О. Каргін. - Донецьк: Норд-Пресс, ДонНУ, 2010. - 526 c. ISBN 978- 966-380-450-4 
6. Спік, М. О. Модель представлення експертних знань в інтелектуальній системі діагностики захворювань [Текст] / М. О. Єпік // International academy journal Web of Scholar ISSN 2518-167X 1(31), Vol.1, January 2019 - Warsaw, Poland: RS Global Sp. z O.O., 2019. - P. 3-7.

7. Єпік, М. О. Механізм нечіткого логічного виведення в інтелектуальній системі діагностики захворювань [Текст] / М.О. Спік // Open Access Peer-reviewed Journal Science Review 2(19), February 2019. - Warsaw, Poland: RS Global Sp. z O.O., 2019. - P. 3-9. ISSN - 2544-9346

8. Крон, Г. Дослідження складних систем по частинах -діакоптика [Текст] / Г. Крон. - М. : Наука, 1972. - 543 с.

9. Zadeh, L. Linear System Theory: The State Space Approach [Text] / L. Zadeh. - New York, United States: Dover Publications Inc., 2008. - 656 p. ISBN100486466639, ISBN13 9780486466637

10. Everest: Платформа «Штучний інтелект» [Електронний ресурс]. - Режим доступу: https://www.everest.ua/ai-platform/.

$\begin{array}{lrr}\text { Епик М. А. } & \text { Концепция } & \text { разработки } \\ \text { интеллектуальной } & \text { системы } & \text { диагностики } \\ \text { заболеваний. } & & \end{array}$

Аннотация. Данная статья посвящена рассмотрению концепции разработки интеллектуальной системы диагностики заболеваний. Проведен обзор современных медицинских интеллектуальных информационных систем. Представлена структура интеллектуальной системы диагностики заболеваний. Подробно описаны этапы разработки концептуальной модели системы.

Ключевые слова: интеллектуальная система, база данных, база знаний, механизм нечеткого логического вывода, концептуальная модель, вербальная модель, нечеткое множество, лингвистическая переменная, нечеткое правило, функция принадлежности.

Iepik M. The development concept for the disease diagnostics intellectual system.

Abstract. The development of the information technologies resulted in a creation of plenty of the medical informative systems from the automated ones to the intellectual systems of decision support. Co-operative complications at the decision making, absence of the terminology standardization and scales of measuring, badly formalized information and knowledge hamper the usage of the intellectual systems in the medical field. These resulted in a way that such systems are the least studied area of the artificial intelligence. The disease diagnostics intellectual system (DDIS) allows modeling of the doctor's thinking process as it applies to the decision making in a specific task, to form certain conclusions, based on the knowledge which the system disposes, to explain achieved result. The development concept of DDIS, which allows the selection of the separate planning stages of the system, is offered in this article. On the stage «Task setting and preliminary research» is determined the purpose and the setting of the system, the expedience of its development and structure. The stage «Mathematical description of the system» is oriented to the database filling (DB) of the DDIS with private algorithms which produce the activity basis of the medic experts and cognitive engineers at the exposure of knowledge. At the stage «Construction of the disease diagnostics verbal model» a medical expert determines the possible amount of linguistic variables and their terms, the transmitters of fuzzy plural limitations for the values of linguistic variables, types and parameters of the membership functions. A cognitive engineer determines the set of fuzzy rules of the «IF... THEN»-type. At the stage «Abstract synthesis of the knowledge base» is carried out the check of knowledge base (KB) for the plenitude, noncontradiction and connectedness. The stage «Construction of the knowledge base» is a process of the rules formalization, described on the stage of the verbal model creation. The stage «Tuning of the knowledge base» is related to tuning of the fuzzy system: construction of the membership functions and forming of rules. On the stage «Minimization of the knowledge base» the number of rules is diminished with the preservation of the KB's exactness. Research is conducted on the plenitude, noncontradiction and connectedness of KB. The stage «Estimation of the DDIS's conceptual model» is related to the estimation of quality indicators of the system's creation and functionality. And the last stage «Realization of the fuzzy model the disease diagnostics» supposes the program realization, testing and analysis of DDIS's performance.

Keywords: intellectual system, database, knowledge base, fuzzy inference mechanism, conceptual model, verbal model, fuzzy set, linguistic variable, fuzzy rule, membership function

\section{Надійшла 27.03.2019p.}

Спік Марина Олександрівна, кандидат технічних наук, дочент кафедри комп'ютерних технологій, Донецький начіональний університет імені Василя Стуса, Вінниия, Україна.

E-mail: marinayepik@gmail.com; m.yepik@donnu.edu.ua ORCID ID: ttps://orcid.org/0000-0001-9021-3680

Iepik Maryna, PhD, candidate of Technical Sciences, senior Lecturer of the computer sciences department, Vasyl' Stus Donetsk National University, Vinnytsia, Ukraine.

E-mail: marinayepik@gmail.com; m.yepik@donnu.edu.ua ORCID ID: ttps://orcid.org/0000-0001-9021-3680 